Investigations

\title{
Developing a System of Organic Farming Technologies to Obtain Environmentally Clean Agricultural Products (Organic Food) in the Steppe Zone of the Kostanai Region
}

\author{
Almabek Batyrzhanovich Nugmanov, Yuriy Valerievich Tulayev, \\ Saniya Abiltaevna Tulkubayeva and Svetlana Vladimirovna Somova \\ Limited Liability Company "Kostanai Research Institute of Agriculture” 12, \\ Yubileinaya Str., Zarechnoye Village, Kostanai District, 111108, Kostanai Region, Republic of Kazakhstan
}

\author{
Article history \\ Received: 13-09-2017 \\ Revised: 03-11-2017 \\ Accepted: 23-12-2017 \\ Corresponding Author: \\ Almabek Batyrzhanovich \\ Nugmanov \\ Limited Liability Company \\ "Kostanai Research Institute of \\ Agriculture" 12, Yubileinaya \\ Str., Zarechnoye Village, \\ Kostanai District, 111108 , \\ Kostanai Region, Republic of \\ Kazakhstan \\ E-mail: sznpz@mail.ru
}

\begin{abstract}
The goal of the research is to study the opportunity to produce environmentally clean agricultural products (organic food) under the conditions of the Kostanai Region. The researches were made in two crop rotations: cereal laying fallow, two-field crop rotation $(1-$ biologized fallow - mustard, 2 - wheat) and cereal laying fallow, two-field crop rotation ( 1 - biologized fallow - grass sorghum, 2 - wheat). Both are formed on stubbles and shredded straw, where wheat cultivation technologies are used. Experimental variants of wheat cultivation are classified into saving organic technologies. Over the 2012-2014 researches, biologized fallows of the Sudan grass happened to be the best forecrops when fighting against weediness of crops both at the fallow stage and for the next crop after the fallow. The cocurrent observations allowed revealing the tendency of improving the erosion resistance of biologized fields occupied by the mustard and Sudan grass for crop residue. Data on the yield for three years say about the efficiency of short crop rotations with biologized fields. Thus, the wheat yield after the grass sorghum for the years of researches made up $17.9 \mathrm{c} / \mathrm{ha}$ - technology $1,18.7 \mathrm{c} / \mathrm{ha}-$ technology 2 and $17.1 \mathrm{c} / \mathrm{ha}$ - technology 3 . After mustard it was $17.0 \mathrm{c} / \mathrm{ha}-$ technology $1,17.9 \mathrm{c} / \mathrm{ha}$ - technology 2 and $19.6 \mathrm{c} / \mathrm{ha}$ - technology 3 . The denial from applying pesticides, along with biologization of fallow fields and applied cultivation technologies made it possible to decrease the content of trace quantities of pesticides in soil and wheat samples at the initial stage of the three years' period and to entirely clean the experimental field and yield from toxic remnants by the end of the three years' researches.
\end{abstract}

Keywords: Organic Farming, Biologized Farming, Crop Rotation, Soil Preparation, Technology, Straw, Grain, Yield

\section{Introduction}

The biological usefulness and food safety are the most important factors that define the state of health and level of the population working capacity. Safety and quality of products define the state prestige and are the basis for meeting needs of every person and the society as a whole. It is the most important component of competitiveness (Remele, 2015; Li et al., 2015).

Over the recent decade in many countries of the world the yield of agricultural crops has increased 2.02.5 times due to both the cultivation of varieties of intensive type and using fertilizers and pesticides. The focus of plant farming intensification on resources and power saving, ecological safety and profitability is stipulated by the need to optimize the use of chemical means in agrobiogeocenoses, first of all, due to biologization and ecologization of production functions of agroecosystems (Atandi et al., 2017; Jeločnik et al., 2015; Andersen et al., 2015; Palšová et al., 2014).

Organic farming (alternative farming) is a reasonable approach to land and plants. Due to it, stable yields are achieved with the minimum expenses and without applying mineral fertilizers and toxic chemicals (Litterick and Watson, 2017; Markuszewska and Kubacka, 2017).

Green fertilizers, stubble and mulch left on the field in case of alternative (organic) farming are the only sources of organic substances in soil that provide intensity of the 
microorganisms' and fauna activity. Green fertilizers themselves are among the basic points the organic farming is based on (Zhirmuskaya, 2006; Bunna et al., 2011; Frøseth et al., 2014; McCalla and Army, 1961).

There is the next important effect of green fertilizers. Their over-ground biomass creates a dense sheet that protects the soil from erosion and mineralization of the organic substance and maintains nutritional chemicals in the upper productive horizon (Mathur et al., 2016; Adnan et al., 2017).

Green fertilizers also play an important sanitary role. Firstly, they suppress the growth of weed. Secondly, some types of green fertilizers contribute to cleaning soil from depredators and diseases. For example, thick planting of mustard considerably decreases the number of wireworms (Green Fertilizer, n. d., 2017).

In its turn, it is necessary to note the compliance with crop rotations under organic farming that provide a higher efficiency of cultivated crops, increase soil fertility and phytosanitary state of fields and decrease the number of depredators, diseases and weediness of crops (Gossen, 1974; Benaragama et al., 2016).

These measures aim at improving the intensity of microbiological processes. Due to them, soil metabolism takes place. As a whole, now the improvement of ecological state of agrocoenosis is one of the main tasks of both the science and practice.

\section{Materials and Methods}

In 2012-2014 field experiment with two two-field crop rotations at cereal laying fallows were conducted. The wheat was seeded after two forecrops - biologized fields after Sudan grass and mustard.

On fields of the two-field crop rotation at cereal laying fallows (biologized fallow by seeing mustard - wheat) three types of wheat cultivation were laid. The same cultivation technologies were laid on fields of the second two-field crop rotation at cereal laying fallows (biologized fallow by sowing Sudan grass - wheat):

1. The biologized technology is a zero technology that allows using glyphosates containing preparations during the presowing period to fight against weed vegetation and seeds fall. Operations on chemical crop tending, as well as seed treatment before sowing are entirely excluded. Harvesting (hay cutting) is carried out by blending crop residues and distributing on the field

2. Biologized technology allows elements to minimize soil processing. Direct sowing by using the A blade is allowed to replace chemical preplanting cultivation. Operations on chemical crop tending, as well as seed treatment before sowing are entirely excluded. Harvesting (hay cutting) is carried out by blending crop residues and distributing on the field
3. Zero technology. Mechanical and chemical tilling is entirely excluded. Only direct sowing by SKP-2.1 seeders reequipped with anchor coulters is carried out. Fight against weed vegetation both in the fallow and for the crop is not allowed. Tilling the material for sowing is not allowed, either. Fertility is supported by leaving all after-harvesting residues in the field

During the research the above technologies were called as technology 1 , technology 2 and technology 3 , respectively.

The experiment was made three times. The area of the crop rotation fields was 0.09 ha $(25 \times 36 \mathrm{~m})$. Between the fields there were headlands with the width of $15 \mathrm{~m}$. The crop rotation fields were located at random.

The researches were made at experimental areas of the Kostanai Agricultural Research Institute LLC near the settlement of Zarechnoye. They were located at the hollow sloping plain of the upper terrace above flood-plain of the right bank of Tobol. They consisted of quaternary alluvial deposits, sand clays, sands, argillaceous clays, clayey soils and clays. The area under research had been used for agricultural production for a long time.

\section{Results}

The climate in the research zone is extremely continental with a cold winter with little snow and hot dry summer. Long cold in spring, early fall of temperature in autumn and late summer rainfalls are typical for the region climate and differentiate it from other dry regions (for example, Povolzhye). Great insolation, stark comparison of day and night temperature, low air humidity, little cloud coverage and frequent winds cause intensive water evaporation that 25 times exceeds the total of atmospheric falls. The end of May and most of June when spring corns are at the tillering stage - stem elongation - are especially dry. Before rainfalls crops have to use quickly disappearing reserves of water accumulated in the soil as a result of winter falls. All climate factors greatly vary from year to year but by tension and time of occurrence.

According to the data for many years, the annual norm of falls in the area of the experiments is $340 \mathrm{~mm}$. Falls of the warm period (April-October) make up 71.2\% of the annual number. Most of them fall down in the latter half of summer.

\section{Weediness of Wheat Depending on Cultivation Technology}

One of the main tasks grain producers face when using the organic method of farming is to suppress weediness of crops. Under other equal conditions, the growth of weediness of crops always causes a yield decrease.

The only possible alternative to modem chemical pesticides in terms of farming ecologization is an 
integrated method of crops protection. One of its variants is the use of biologized fallows with green fertilizers for crop residues where the density of crops is increased and there are no favorable conditions for weed vegetation.

Weediness of crops at the stage of fully germinated wheat was observed annually (Table 1).

According to the data for three years, the wheat after mustard was mostly weeded. At the same time perennial weed vegetation prevailed. In terms of technologies, wheat after mustard was mostly weeded when technology 2 was used $-8.7 \mathrm{pcs} / \mathrm{m}^{2}$ with many wet and dry weed vegetation. On the fields where technologies 1 and 3 were used weediness of crops was considerably lower - 3.9-5.7 pcs. $/ \mathrm{m}^{2}$.

In case of technology $3\left(2.1 \mathrm{pcs} . / \mathrm{m}^{2}\right)$ with the weight of weed vegetation - 7.5-1.8 g, wheat after Sudan grass was the most weeded.

Sowing of Sudan grass and mustard at the full germination phase were weeded almost equally both by quantity and weed vegetation weight. However, in case of Sudan grass, there was equal species composition of weed vegetation, while on mustard fields yearling fields prevailed.

It is also necessary to note that on fields where technologies $2\left(8.5 \mathrm{pcs} . / \mathrm{m}^{2}\right)$ and $3\left(10.4 \mathrm{pcs} . / \mathrm{m}^{2}\right)$ were used, Sudan grass was more weeded that on fields were technology $1\left(3.2 \mathrm{pcs} . / \mathrm{m}^{2}\right)$ was used. It was the same with mustard fields when fields with technologies 2 and 3 (13.7-6.9 pcs. $\left./ \mathrm{m}^{2}\right)$ used were more weeded than the field with technology $1\left(2.2 \mathrm{pcs} . / \mathrm{m}^{2}\right)$ used.

Since this experiment does not provide herbicide preparation of sowing, by the harvest the number of weed vegetation in wheat has increased (Table 2).

The analysis of Table 2 says that for the years of researches the greatest weediness of crops before harvesting was found on wheat after mustard, the least was found on wheat fields of Sudan grass both by quantity and weight. It says about the efficiency of Sudan grass as a forecrop when fighting against weed vegetation.

\section{Erosion Resistance of the Fallow Field}

Fallow fields in experiments were seeded with Sudan grass and mustard. One of the research goals was to determine the optimal forecrop to fight against water, wind erosion.

In 2012-2014 the sowing was carried out on the wheat stubble + shredded straw both by cultivation technologies and depending on the forecrop. The results of accounting the crop weight before the fallow by the background are shown in Table 3.

Table 1: Fully germinated weediness of crops, pcs./ $\mathrm{m}^{2}$ (2012-2014)

\begin{tabular}{|c|c|c|c|c|c|c|}
\hline \multirow[b]{3}{*}{ Fields of crop rotation } & \multirow[b]{3}{*}{ Technology } & \multicolumn{3}{|c|}{ Amount of weed vegetation $\left(\mathrm{pcs} . / \mathrm{m}^{2}\right)$} & \multirow{3}{*}{$\begin{array}{l}\text { Weight of } \\
\text { wet mass }(\mathrm{g})\end{array}$} & \multirow{3}{*}{$\begin{array}{l}\text { Weight of } \\
\text { dry mass }(\mathrm{g})\end{array}$} \\
\hline & & \multirow[b]{2}{*}{ In total } & \multicolumn{2}{|l|}{ Including } & & \\
\hline & & & Yearling & Perennial & & \\
\hline \multirow[t]{3}{*}{ Wheat after mustard } & Technology 1 & 3.9 & 0.2 & 3.7 & 11.3 & 2.7 \\
\hline & Technology 2 & 8.7 & 3.3 & 5.3 & 17.5 & 3.2 \\
\hline & Technology 3 & 5.7 & 0.8 & 4.9 & 8.5 & 1.7 \\
\hline \multirow[t]{3}{*}{ Wheat after Sudan grass } & Technology 1 & 0.6 & 0.1 & 0.5 & 2.4 & 0.5 \\
\hline & Technology 2 & 0.5 & - & 0.5 & 6.5 & 1.3 \\
\hline & Technology 3 & 2.1 & 0.8 & 1.3 & 7.5 & 1.8 \\
\hline \multirow[t]{3}{*}{ Sudan grass } & Technology 1 & 3.2 & 0.4 & 2.9 & 7.2 & 1.6 \\
\hline & Technology 2 & 8.5 & 4.9 & 3.6 & 13.4 & 4.0 \\
\hline & Technology 3 & 10.4 & 5.3 & 5.1 & 13.3 & 3.3 \\
\hline \multirow[t]{3}{*}{ Mustard } & Technology 1 & 2.2 & 1.6 & 0.5 & 2.4 & 0.8 \\
\hline & Technology 2 & 13.7 & 11.4 & 2.3 & 14.4 & 3.7 \\
\hline & Technology 3 & 6.9 & 4.7 & 2.2 & 7.8 & 3.4 \\
\hline
\end{tabular}

Table 2: Weediness of crops before harvesting, pcs. $/ \mathrm{m}^{2}$ (2013-2014)

\begin{tabular}{|c|c|c|c|c|c|c|}
\hline \multirow[b]{3}{*}{ Fields of crop rotation } & \multirow[b]{3}{*}{ Technology } & \multicolumn{3}{|c|}{ Amount of weed vegetation (pcs. $/ \mathrm{m}^{2}$ ) } & \multirow{3}{*}{$\begin{array}{l}\text { Weight of } \\
\text { wet mass }(\mathrm{g})\end{array}$} & \multirow{3}{*}{$\begin{array}{l}\text { Weight of } \\
\text { dry mass (g) }\end{array}$} \\
\hline & & \multirow[b]{2}{*}{ In total } & \multicolumn{2}{|l|}{ Including } & & \\
\hline & & & Yearling & Perennial & & \\
\hline \multirow[t]{3}{*}{ Wheat after mustard } & Technology 1 & 40.9 & 39.9 & 1.0 & 83.3 & 22.4 \\
\hline & Technology 2 & 90.3 & 42.8 & 3.5 & 83.1 & 22.7 \\
\hline & Technology 3 & 25.5 & 20.5 & 5.0 & 74.7 & 18.8 \\
\hline \multirow[t]{3}{*}{ Wheat after Sudan grass } & Technology 1 & 15.8 & 29.0 & 1.3 & 32.6 & 8.4 \\
\hline & Technology 2 & 12.3 & 7.8 & 4.5 & 57.4 & 12.2 \\
\hline & Technology 3 & 12.3 & 9.3 & 3.0 & 17.5 & 5.8 \\
\hline
\end{tabular}


Table 3: Content and structure of residues before fallow in the soil layer of 0-5 $\mathrm{cm}$ (2012-2014)

\begin{tabular}{|c|c|c|c|c|c|c|c|}
\hline \multirow[b]{2}{*}{ Fields of crop rotation } & \multirow[b]{2}{*}{ Technology } & \multirow[b]{2}{*}{$\begin{array}{l}\text { Weight of } \\
\text { residues }\left(\mathrm{g} / \mathrm{m}^{2}\right)\end{array}$} & \multicolumn{2}{|c|}{ Including by fractions } & \multicolumn{2}{|c|}{$\begin{array}{l}\text { Number of crops } \\
\text { fragments }\left(\mathrm{pcs} . / \mathrm{m}^{2}\right)\end{array}$} & \multirow{2}{*}{$\begin{array}{l}\text { Average } \\
\text { length of } \\
\text { residues }(\mathrm{cm})\end{array}$} \\
\hline & & & $\begin{array}{l}\text { Stubbles } \\
\text { with roots }\end{array}$ & $\begin{array}{l}\text { Residues } \\
\text { without roots }\end{array}$ & $\begin{array}{l}\text { Stubbles } \\
\text { with roots }\end{array}$ & $\begin{array}{l}\text { Residues } \\
\text { without roots }\end{array}$ & \\
\hline \multirow[t]{3}{*}{ Wheat after Sudan grass } & Technology 1 & 1.016 & 286 & 730 & 177 & 4,105 & 13.0 \\
\hline & Technology 2 & 824 & 229 & 588 & 172 & 2,884 & 12.1 \\
\hline & Technology 3 & 635 & 175 & 460 & 168 & 3,040 & 12.4 \\
\hline \multirow[t]{3}{*}{ Wheat after mustard } & Technology 1 & 778 & 227 & 550 & 183 & 3,477 & 10.1 \\
\hline & Technology 2 & 678 & 189 & 438 & 178 & 2,982 & 9.6 \\
\hline & Technology 3 & 573 & 168 & 410 & 176 & 3,297 & 9.6 \\
\hline
\end{tabular}

The analysis of the research data obtained for 20122014 showed that when cultivating by using technology 1 at the beginning of fields biologized fallow with Sudan grass, there was more accumulated stubble both by the weight $\left(1,016 \mathrm{~g} / \mathrm{m}^{2}\right)$ and size and number of fractions. When cultivating by using technologies 2 and 3, these indicators decreased and equaled.

\section{Density of the Arable Layer of Soil, Food Regime of Soil}

Southern light loamy black soils have a satisfactory composition both in the cultivable and humous layers of the soil (up to $60-70 \mathrm{~cm}$ ). In case of ordinary agricultural technique, such soils preserve the composition given by the main preparation for a long time.

The soil density has various influences on a plant. Its excessive tightening can complicate the growth of roots. If the density of heavy soils is $1.5-1.6 \mathrm{~g} / \mathrm{cm}^{3}$, the level of inaccessible moisture for plants dramatically increases. The optimal density fluctuation margin for basic crops cultivated in the north of Kazakhstan is within 1.1-1.3 $\mathrm{g} / \mathrm{cm}^{3}$. According to numerous researches, the optimal volume weight for cereals is $1.10-1.20 \mathrm{~g} / \mathrm{cm}^{3}$ and it is close to the balanced density of these soils $\left(1.17-1.25 \mathrm{~g} / \mathrm{cm}^{3}\right)$.

In our researches the volume weight of the cultivable layer was defined at the beginning of the fallow, on cereals fields - before sowing according to backgrounds (Table 4).

As a whole, the analysis of the obtained samples of the volume weight said about the optimal density in practice and no distinct dependence between cultivation technologies was observed for 2012-2014.

Assessment of the initial state of the soil by the content of the main elements of mineral nutrition in the spring from 2012-2014. Before sowing, the nitrogen content of nitrate $\left(\mathrm{N}-\mathrm{NO}_{3}\right)$ and Phosphorus Oxide $\left(\mathrm{P}_{2} \mathrm{O}_{5}\right)$ in the "arable" soil layer was determined. The results of analyze of the crop rotation for the years 2012-2014 are summarized in Table 5.

Analysis of soil samples by years shows that the wheat fields after the Sudan grass in the $0-40 \mathrm{~cm}$ layer by the nitrogen content of the nitrate have a low degree of supply. According to the content of phosphorus oxide, the fields have increased safety.

\section{Yield of Spring Wheat Depending on Cultivation Technology}

One of the tasks of this research is to obtain environmentally clean agricultural products under the decrease in the irreparable power consumption, the decrease in the intensity of the humus mineralization and due to fuller use of residues, accumulation of the organic substance in the upper soil layer and optimization of water and physical features. Along with this, it is necessary to obtain the maximum yield without applying any mechanical interference, except for sowing to prevent erosion processes in soil.

In order to obtain the maximum yield, it is also of great interest to use non-synthesized modern biopreparations that ensure efficiency and safety for people and the environment. Thus, since 2012 to 2014 a number of non-synthesized preparations such as Humilife, Zircon and Riverm have been applied. All of them are made of vegetable stock. The preparations were applied by sprinkling vegetative plants at the tillering phase and under the spring wheat earing. Table 6 shows the data on the yield.

In 2012 the yield was obtained on the general background of wheat stubble and blended crop residues. That year the Zircon non-synthesized preparation was applied.

Considering the table data, in terms of applying the growth regulator, considerable growth is observed from applying the Zircon preparation. In case of technology 1, the use of the growth stimulator added $+1.6 \mathrm{~cm}$ (or $19.5 \%$ ) as to the control (Technology 1 without using Zircon). In case of technology 2+Zircon, the yield was $10.1 \mathrm{c} / \mathrm{ha}$ and $+0.7 \mathrm{c} /$ ha or $7.4 \%$ was added, which in terms of fertilizers was considerable. The growth was also observed in case of technology $3+$ Zircon as to the control (technology 3 without preparation). Here the yield (11.0 $\mathrm{c} / \mathrm{ha}$ ) exceeded the control variant by $1.6 \mathrm{c} / \mathrm{ha}$ or $17.0 \%$. 
Almabek Batyrzhanovich Nugmanov et al. / OnLine Journal of Biological Sciences 2018, 18 (2): 130.137 DOI: 10.3844/ojbsci.2018.130.137

Table 4: Volume weight of soil before sowing and at the beginning of fallow by fields of crop rotation in the layer of 0-30 $\mathrm{cm}(2012-2014)$ Density $\left(\mathrm{g} / \mathrm{cm}^{3}\right)$

\begin{tabular}{|c|c|c|c|c|c|}
\hline \multirow[b]{2}{*}{ Fields of crop rotation } & \multirow[b]{2}{*}{ Cultivation technology } & & & & \\
\hline & & 2012 & 2013 & & Average in $2012-2014$ \\
\hline \multirow[t]{2}{*}{ Wheat after Sudan grass } & Zero & 1.10 & 1.20 & 1.18 & 1.15 \\
\hline & Minimum & 1.09 & 1.21 & 1.18 & 1.16 \\
\hline \multirow[t]{2}{*}{ Wheat after mustard } & Zero & 1.09 & 1.09 & 1.14 & 1.11 \\
\hline & Minimum & 1.09 & 1.15 & 1.10 & 1.11 \\
\hline \multirow[t]{2}{*}{ Sudan grass } & Zero & 1.09 & 1.16 & 1.16 & 1.13 \\
\hline & Minimum & 1.09 & 1.14 & 1.18 & 1.14 \\
\hline \multirow[t]{2}{*}{ Mustard } & Zero & 1.09 & 1.21 & 1.12 & 1.14 \\
\hline & Minimum & 1.09 & 1.21 & 1.11 & 1.13 \\
\hline
\end{tabular}

Table 5: Content of basic nutrients in the soil layer 0-20, 20-40 cm, before sowing (2012-2014)

\begin{tabular}{|c|c|c|c|c|}
\hline \multirow[b]{2}{*}{ Crop rotation fields } & \multirow[b]{2}{*}{ Technology options } & \multirow[b]{2}{*}{ Layer of soil $(\mathrm{cm})$} & \multicolumn{2}{|c|}{ Contains $\mathrm{mg} / \mathrm{kg}$ of soil } \\
\hline & & & $\mathrm{N}-\mathrm{NO}_{3}$ & $\mathrm{P}_{2} \mathrm{O}_{5}$ \\
\hline \multirow[t]{9}{*}{ Wheat after Sudan grass } & Technology 1 & $0-20$ & 8,0 & 142,7 \\
\hline & & $20-40$ & 6,9 & 121,8 \\
\hline & & $0-40$ & 7,5 & 132,3 \\
\hline & Technology 2 & $0-20$ & 9,2 & 125,1 \\
\hline & & $20-40$ & 8,5 & 98,5 \\
\hline & & $0-40$ & 8,9 & 111,8 \\
\hline & Technology 3 & $0-20$ & 9,0 & 133,7 \\
\hline & & $20-40$ & 8,5 & 114,0 \\
\hline & & $0-40$ & 8,8 & 123,9 \\
\hline \multirow[t]{9}{*}{ Wheat after mustard } & Technology 1 & $0-20$ & 10,1 & 152,0 \\
\hline & & $20-40$ & 9,5 & 120,2 \\
\hline & & $0-40$ & 9,8 & 136,0 \\
\hline & Technology 2 & $0-20$ & 10,3 & 140,5 \\
\hline & & $20-40$ & 10,0 & 117,5 \\
\hline & & $0-40$ & 10,2 & 129,0 \\
\hline & Technology 3 & $0-20$ & 10,5 & 142,3 \\
\hline & & $20-40$ & 10,7 & 135,3 \\
\hline & & $0-40$ & 10,6 & 138,8 \\
\hline
\end{tabular}

Table 6: Yield of wheat grains depending on cultivation technology and applying non-synthesized preparations (2012)

\begin{tabular}{|c|c|c|c|c|c|c|}
\hline \multirow[b]{2}{*}{ Experiment variant } & & \multirow[b]{2}{*}{ Average yield, c/ha } & & \multicolumn{3}{|l|}{ Yield growth } \\
\hline & & & & $\mathrm{c} / \mathrm{ha}$ & & $\%$ \\
\hline Technology 1 & & 8.2 & & - & & 100 \\
\hline Technology 2 & & 9.4 & & +1.2 & & +14.6 \\
\hline Technology 3 & & 9.4 & & +1.2 & & +14.6 \\
\hline Technology 1+Zirconium & & 9.8 & & +1.6 & & +19.5 \\
\hline Technology 2+ Zirconium & & 10.1 & & +0.7 & & +7.4 \\
\hline Technology $3+$ Zirconium & & 11.0 & & +1.6 & & +17.0 \\
\hline $\mathrm{HCP}_{05} \quad$ technology & $=$ & $\mathrm{HCP}_{05}$ & growth & stimulator & $=$ & 0.5 \\
\hline
\end{tabular}

Table 7: Yield of wheat grains depending on cultivation technology and applying non-synthesized preparations (2013-2014)

\begin{tabular}{|c|c|c|c|c|c|c|c|c|c|c|c|c|c|}
\hline \multirow{2}{*}{$\begin{array}{l}\text { Place of wheat } \\
\text { in crop rotation }\end{array}$} & & \multicolumn{4}{|c|}{ Technology1 } & \multicolumn{4}{|c|}{ Technology 2} & \multicolumn{4}{|c|}{ Technology 3} \\
\hline & & Control & Humilife & Zircon & Riverm & Control & Humilife & Zircon & Riverm & Control & Humilife & Zircon & Riverm \\
\hline \multirow[t]{2}{*}{ Wheat after Sudan grass } & 2013 & 15.0 & 15.3 & 16.7 & 15.5 & 14.1 & 14.7 & 14.7 & 14.6 & 14.4 & 13.8 & 14.0 & 14.3 \\
\hline & 2014 & 20.9 & 21.3 & 20.8 & 19.7 & 22.7 & 21.1 & 21.0 & 22.1 & 19.7 & 19.6 & 16.8 & 17.8 \\
\hline Average & 2013-2014 & 17.9 & 18.3 & 18.8 & 17.6 & 18.7 & 17.9 & 17.9 & 18.4 & 17.1 & 16.7 & 15.4 & 16.1 \\
\hline \multicolumn{14}{|c|}{$\mathrm{HCP}_{05}$ technologies $=1.82 ; \mathrm{HCP}_{05}$ fertilizer $=1.70$} \\
\hline \multirow[t]{2}{*}{ Wheat after mustard } & 2013 & 13.7 & 16.3 & 15.9 & 14.2 & 14.1 & 13.0 & 13.5 & 14.5 & 15.0 & 14.4 & 13.3 & 11.9 \\
\hline & 2014 & 20.2 & 21.5 & 18.7 & 19.1 & 21.6 & 23.5 & 21.6 & 20.2 & 24.1 & 23.7 & 22.0 & 21.4 \\
\hline Average & 2013-2014 & 17.0 & 18.9 & 17.3 & 16.7 & 17.9 & 17.3 & 17.6 & 17.4 & 19.6 & 19.1 & 17.7 & 16.7 \\
\hline \multicolumn{14}{|c|}{$\mathrm{HCP}_{05}$ technologies $=2.09 ; \mathrm{HCP}_{05}$ fertilizer $=1.06 ; \mathrm{HCP}_{05}$ forecrop $=2.3$} \\
\hline
\end{tabular}


Table 8: Remaining microquantity of pesticides in soil and grains samples (2012-2013)

\begin{tabular}{|c|c|c|c|c|c|c|c|}
\hline \multirow[b]{3}{*}{ Preparation } & \multirow[b]{3}{*}{ Active material } & \multicolumn{6}{|c|}{ Content of active material $(\mathrm{mg} / \mathrm{kg})$} \\
\hline & & \multicolumn{3}{|l|}{ Grains } & \multicolumn{3}{|l|}{ Soil } \\
\hline & & 2012 & 2013 & 2014 & 2012 & 2013 & 2014 \\
\hline Uragan forter & glyphosate* & 0.00 & 0.00 & 0.00 & 0.00 & 0.00 & 0.00 \\
\hline \multirow{2}{*}{ Secator turbo } & iodosulphrone & 0.102 & 0.081 & 0.00 & 0.00 & 0.04 & 0.00 \\
\hline & amidosulphrone & 0.00 & 0.00 & 0.00 & 0.00 & 0.00 & 0.00 \\
\hline Bars super & phenoxaprop-p-ethyl & 0.00 & 0.00 & 0.00 & 0.00 & 0.00 & 0.00 \\
\hline \multirow[t]{3}{*}{ Phalkon } & spiroxamine & 0.00 & 0.00 & 0.00 & 0.00 & 0.00 & 0.00 \\
\hline & tebuconazole & 0.00 & 0.00 & 0.00 & 0.00 & 0.00 & 0.00 \\
\hline & triadimenol & 0.00 & 0.00 & 0.00 & 0.00 & 0.00 & 0.00 \\
\hline \multirow{2}{*}{ Vitavaks } & carboxin & 0.00 & 0.00 & 0.00 & 0.00 & 0.00 & 0.00 \\
\hline & thiram & 0.018 & 0.00 & 0.00 & 0.00 & 0.00 & 0.00 \\
\hline Karate & lambda-cyhalothrin & 0.00 & 0.00 & 0.00 & 0.00 & 0.00 & 0.00 \\
\hline
\end{tabular}

*- samples of grain and soil were selected from the technologies that do not allow using pesticides. However, the availability of glyphosate was defined both in technologies 2 and 3 and 1 where its use was allowed during the presowing period

During the next years in practiced several nonsynthesized preparations that regulate the growth and development of plants were used. Table 7 shows the data.

The analysis of Table 7 showed that the average yield of wheat after Sudan grass for 2013-2014 was $17.9 \mathrm{c} / \mathrm{ha}$ with technology 1 applied; technology $2-18.7 \mathrm{c} / \mathrm{ha}$; and technology 3-17.1 c/ha. No considerable difference between the technologies was revealed.

\section{Residues of Microquantity of Pesticides in Soil and Wheat Grains Samples}

It is necessary to consider the period when the soil and grains are entirely cleaned as the final stage of the experiment. According to the references, to clean soil and consequently the obtained products from the remaining microquantities of pesticides, three and more years are required.

Due to it, we selected samples of soil and grains to control subject to the remnants of pesticides. This control includes quantitative and qualitative analysis of data about using pesticides in the area under research during the previous years (at least 5 years), the selection itself and preparation of samples and analysis by using the chromatographic method. Table 8 shows the data obtained for 2012-2013.

\section{Discussion}

\section{Weediness of Wheat Depending on Cultivation Technology}

On average for 3 years wheat sowing after Sudan grass was the cleanest at the beginning of the vegetation stage. Technologies 1 and 2 show a low number of weed vegetation $\left(0.6-0.5 \mathrm{pcs} . / \mathrm{m}^{2}\right)$. However, on the field where technology 2 was used dry and wet number of weed vegetation was higher $(6.5-1.3 \mathrm{~g})$ than on the field where technology 1 was used $\left(2.4-0.5 \mathrm{pcs} . / \mathrm{m}^{2}\right)$.
In terms of technologies the field with technology 2 used was weeded. Technologies 1 and 3 had equal weed vegetation by both forecrops.

\section{Erosion Resistance of the Fallow Field}

As a result of selecting stubble and mulch by technologies from wheat fields after mustard, it was revealed that the researched indicators for technology 1 prevailed both by the weight $\left(778 \mathrm{~g} / \mathrm{m}^{2}\right)$ and fraction size. Technologies 2 and 3 inconsiderably lost by accumulating crop residues.

\section{Density of the Arable Layer of Soil, Food Regime of Soil}

It is necessary to note that based on the density indicators for 2012, there was a kind of its increase in 1.5 years at separate areas of fields. However, finally the data become equal and even a kind of its decrease was observed.

The wheat fields after the mustard (in the 0-40 layer) had average $\mathrm{N}-\mathrm{NO}_{3}$ indices at technologies 2 and 3 (10.2 and $10.6 \mathrm{mg} / \mathrm{kg}$ ), the technology 1 was slightly inferior. According to the stocks of $\mathrm{P}_{2} \mathrm{O}_{5}$, wheat after the mustard had an increased level of safety.

\section{Yield of Spring Wheat Depending on Cultivation Technology}

The control cultivation of wheat after mustard (without preparations) for the years of the research made it possible to obtain the following yield: $17.0 \mathrm{c} / \mathrm{ha}-$ technology $1 ; 17.9 \mathrm{c} / \mathrm{ha}$ - technology 2 ; and $19.6 \mathrm{c} / \mathrm{ha}-$ technology 3 . There was no considerable growth from the applied growth regulators as to the control variants.

\section{Residues of Microquantity of Pesticides in Soil and Wheat Grains Samples}

In 2014 the results of the analysis were obtained to say about the complete clearance of the soil area. The active 
substances iodosulphrone-methyl-sodium and thiram were not found in samples of soil and wheat grains.

\section{Conclusion}

The Republic of Kazakhstan has a significant potential in the field of organic farming. The production of environmentally friendly products is an important direction for the development of the "green economy", approved by the Government and included in the country's program, signed with the international organization of FAO. In accordance with this project, environmental legislation is being introduced, a national strategic plan is being created and a system of environmental certification and rules for controlling organic production in the Republic of Kazakhstan is being formed. Today in Kazakhstan there are a number of farms that specialize in the production of organic products. In general, there are about 30 producers of organic products in the republic, of which 22 farms are certified for the production of organic products in Kostanay region, with a total area of 294878 hectares:

1. On average for the years of the research the wheat sowing after Sudan grass was the cleanest at the beginning of the vegetation. For the years of the research weediness of crops before harvesting was most found on fields with wheat seeded after mustard, least - on wheat field after Sudan grass both by the quantity and weight. In terms of technologies the field with technology 2 used was the most weeded. Fields with technologies 1 and 3 used were equally weeded by both forecrops

2. Mass accumulation of plant residues was found even after the wheat vegetation, which is a positive tendency on the way to the phytosanitary cleanness of fields and decrease in the humidity loss which naturally suppresses erodibility processes on the soil surface

3. At the moment of sowing the wheat fields after mustard were less puddled. Thus, on the fields where zero and minimum technologies were used, the soil density was the same $-1.11 \mathrm{~g} / \mathrm{cm}^{3}$ and on fields where there was wheat after Sudan grass it was $1.15 \mathrm{~g} / \mathrm{cm}^{3}$ with the zero technology used and $1.16 \mathrm{~g} / \mathrm{cm}^{3}$ with the minimum technology used. However, this density is close to the balanced and is not an obstacle on the way to good yield

4. Applying non-synthesized preparations for the research years as to the control variant did not cause the yield growth. It is necessary to note that for the research years no yield differences between applied crop rotations have been revealed
5. The data obtained for 2012-2014 say about the decrease in the reserves of microquantity of pesticides due to natural processes in the soil on the experimental field up to full clearance. Besides, the fact that pesticides were exclusively used during the vegetation as a method of fighting against weed vegetation, diseases and wheat blasts also contributes to non-accumulation of a number of pesticides

According to the results of the conducted studies, it has been established that the best technology for the production of organic grains is technology 2 , since it is the most complete set of research tasks.

\section{Acknowledgement}

We thank our Institute for supporting our work.

\section{Author's Contributions}

All authors contributed equally.

\section{Ethics}

Authors declared no conflicts of interest.

\section{References}

Adnan, N., S. Nordin, I. Rahman and A. Noor, 2017. Adoption of green fertilizer technology among paddy farmers: A possible solution for Malaysian food security. Land Use Policy, 63: 38-52.

Andersen, M.M., X. Landes, W. Xiang, A. Anyshchenko and M.G. Palmgren, 2015. Feasibility of new breeding techniques for organic farming. Trends Plant Sci., 20: 426-434.

Atandi, J.G., S. Haukeland, G.M. Kariuki, D.L. Coyne and N. Adamtey, 2017. Organic farming provides improved management of plant parasitic nematodes in maize and bean cropping systems. Agric. Ecosystems Environ., 247: 265-272.

Benaragama, D., S.J. Shirtliffe, B.D. Gossen, S.A. Brandt and C. Stevenson, 2016. Long-term weed dynamics and crop yields under diverse crop rotations in organic and conventional cropping systems in the Canadian prairies. Field Crops Res., 196: 357-367.

Bunna, S., P. Sinath, O. Makara, J. Mitchell and S. Fukai, 2011. Effects of straw mulch on mungbean yield in rice fields with strongly compacted soils. Field Crops Res., 124: 295-301.

Frøseth, R.B., A.K. Bakken, M.A. Bleken, H. Riley and S. Hansen, 2014. Effects of green manure herbage management and its digestate from biogas production on barley yield, $\mathrm{N}$ recovery, soil structure and earthworm populations. European J. Agronomy, 52: 90-102. 
Gossen, E.F., 1974. Osobennosti sistemy zemledeliya v komplekse agrotehnicheskih i organizatsionnoekonomicheskih meropriyatiy po borbe s zasuhoy $\mathrm{v}$ usloviyah Severnogo Kazahstana. Problemy borby s zasuhoy i rost proizvodstva selskohozyaystvennoy produktsii [Peculiarities of farming system in the complex of agro-technical and organization and economic measures on fighting against drought under the conditions of the North Kazakhstan. Problems of fighting against drought and growth of agricultural production]. Moscow.

Green Fertilizer, n. d., 2017. Zelenoe udobrenie [Green fertilizers].

Jeločnik, M., R.A. Ion, M. Jovanović and C.G. Popescu, 2015. Has organic farming potential for development? Comparative Study in Romania and Serbia. Procedia Economics Finance, 22: 268-276.

Li, Z.M., N.S. Su, X.X. Dong, Y.T. Yang and H.L. Xiao, 2015. Edible agro-products quality and safety in China. J. Integrative Agric., 14: 2166-2175.

Litterick, A.M. and C.A. Watson, 2017. Organic Farming. In: Encyclopedia of Applied Plant Sciences, Elsevier Ltd,

ISBN-10: 978-0-12-394807-6, pp: 311-317.
Markuszewska, I. and M. Kubacka, 2017. Does Organic Farming (OF) work in favour of protecting the natural environment? A case study from Poland. Land Use Policy, 67: 498-507.

Mathur, A., F. Dias and P. Mathur, 2016. Importance of green technology in fertilizer quality improvement. Procedia Eng., 138: 308-313.

McCalla, T.M. and T.J. Army, 1961. Stubble mulch farming. Adv. Agronomy, 13: 125-196.

Palšová, L., L. Schwarczová, P. Schwarcz and A. Bandlerová, 2014. The support of implementation of organic farming in the Slovak republic in the context of sustainable development. Procedia-Soc. Behavioral Sci., 110: 520-529.

Remele, V.V., 2015. Ekologicheski chistye bakterialnye preparaty dlya zaschity zernovyh kultur ot gribnyh bolezney [Ecologically clean bacterial germicides for protecting grain crops from fungous diseases]. Bulletin Kazakh Agric. Sci., 5: 30-30.

Zhirmuskaya, N.M., 2006. Vse o sideratah [All about leies]. Center for Ecological Farming, Dnepropetrovsk, pp: 60. 